\title{
Cytokine "fine tuning" of enthesis tissue homeostasis as a pointer to spondyloarthritis pathogenesis with a focus on relevant TNF and IL-17 targeted therapies
}

\author{
Tobias Russell $^{1}$ (D) Charlie Bridgewood $^{1}$ (D) $\cdot$ Hannah Rowe $^{1}$ (D) $\cdot$ Ala Altaie $^{1} \cdot$ Elena Jones $^{1}$ (D) $\cdot$ Dennis McGonagle $^{1,2}$ (D)
}

Received: 14 October 2020 / Accepted: 4 January 2021 / Published online: 5 February 2021

(C) The Author(s) 2021

\begin{abstract}
A curious feature of axial disease in ankylosing spondylitis (AS) and related non-radiographic axial spondyloarthropathy (nrAxSpA) is that spinal inflammation may ultimately be associated with excessive entheseal tissue repair with new bone formation. Other $\mathrm{SpA}$ associated target tissues including the gut and the skin have well established paradigms on how local tissue immune responses and proven disease relevant cytokines including TNF and the IL-23/17 axis contribute to tissue repair. Normal skeletal homeostasis including the highly mechanically stressed entheseal sites is subject to tissue microdamage, microinflammation and ultimately repair. Like the skin and gut, healthy enthesis has resident immune cells including ILCs, $\gamma \delta \mathrm{T}$ cells, conventional CD4+ and CD8+ T cells and myeloid lineage cells capable of cytokine induction involving prostaglandins, growth factors and cytokines including TNF and IL-17 that regulate these responses. We discuss how human genetic studies, animal models and translational human immunology around TNF and IL-17 suggest a largely redundant role for these pathways in physiological tissue repair and homeostasis. However, disease associated immune system overactivity of these cytokines with loss of tissue repair "fine tuning" is eventually associated with exuberant tissue repair responses in AS. Conversely, excessive biomechanical stress at spinal enthesis or peripheral enthesis with mechanically related or degenerative conditions is associated with a normal immune system attempts at cytokine fine tuning, but in this setting, it is commensurate to sustained abnormal biomechanical stressing. Unlike SpA, where restoration of aberrant and excessive cytokine "fine tuning" is efficacious, antagonism of these pathways in biomechanically related disease may be of limited or even no value.
\end{abstract}

Keywords Spondyloarthritis $\cdot$ Enthesis $\cdot \mathrm{IL}-17 \cdot \mathrm{TNF}$

\section{Introduction}

The seronegative spondyloarthropathies ( $\mathrm{SpA})$ include ankylosing spondylitis (AS), non-radiographic axial SpA $(\mathrm{nrAxSpA})$ are associated with post-inflammatory excessive tissue repair responses manifesting as new bone formation

This article is a contribution to the Special issue on: Spondyloarthritis Guest Editors: Robert Inman \& Nigil Haroon

Dennis McGonagle

D.G.McGonagle@leeds.ac.uk

1 Leeds Institute of Rheumatic and Musculoskeletal Medicine (LIRMM), University of Leeds, Leeds, UK

2 Section of Musculoskeletal Disease, Leeds Institute of Molecular Medicine, University of Leeds, NIHR Leeds Musculoskeletal Biomedical Research Unit, Chapel Allerton Hospital, Leeds, UK
[1]. This is in contra-distinction to rheumatoid arthritis (RA) where inflammation is associated with predictable bone and cartilage destruction [2]. Beyond the skeleton, including the axial skeleton, the skin, gut and occasionally the arterial tree are target tissues in the axial SpA. The skin, gut and aortic root are biomechanically stressed or chemically stressed sites that are associated with damage and repair responses $[1,3]$. There is a considerable body of literature describing how different immune cells and cytokines including TNF, IL-23, IL-22, IL-17 family member cytokines and others are involved in tissue repair responses [4-6] (Fig. 1). The role of these molecules in the skin and gut homeostasis is not the subject of this perspective and is well reviewed elsewhere [7,8]. The purpose of this article is to apply this concept to understanding axial SpA in the context of entheseal biology and translationally relevant cytokines and other molecules and to consider the same concept in relationship to degenerative enthesopathy and tendinopathy. 


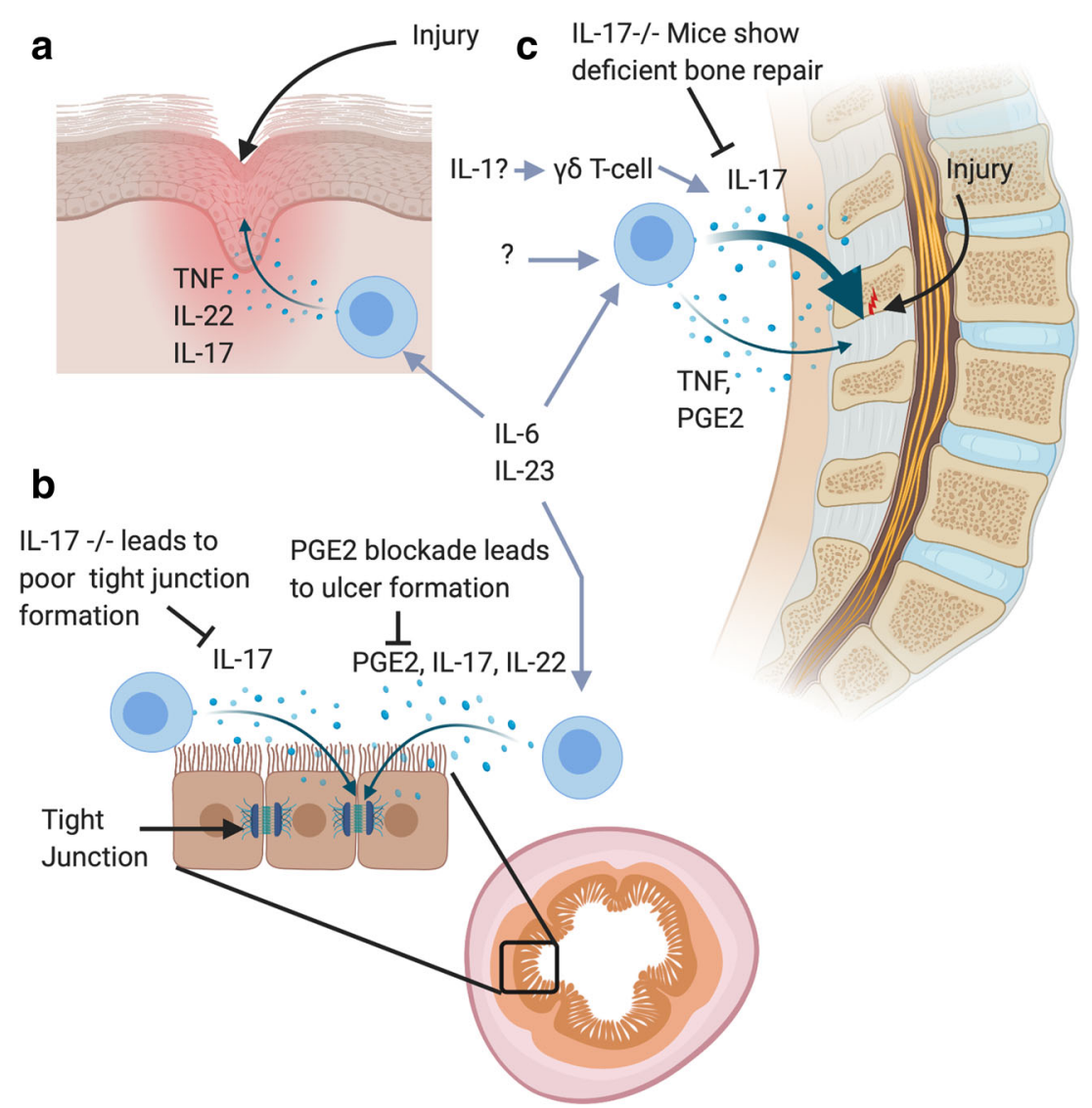

Fig. 1 The spondyloarthropathy target tissues beyond the spine including the gut and the skin have a well-established understanding whereby the immune system plays a key role in physiological tissue repair. a Damage to the skin leads to rapid influx of immune cells producing cytokines including TNF, IL-17 and IL-22 which are involved in keratinocyte proliferation and extra cellular matrix deposition. b The evidence for microdamage to the spinal enthesis and how this regulates of IL-17A, TNF and PGE2 at entheses and tendons is discussed in the text. Mouse knockouts for IL-17A show impaired fracture healing responses which is rescued by IL-17A supplementation. c The hostile enzymatic and microbial normal gut environment is associated with tissue microdamage. IL-23, IL-22, IL-17A, IL-22 or PGE2 play key roles in gut homeostasis in experimental models. In particular, IL-17A plays a pivotal role in the tight junction formation between cells are damaged resulting in leaky gut
Therapeutically, AS responds to anti-cytokine targeting including anti-TNF, anti-IL-17 blockers and also good responses to cyclooxygenase (COX) enzyme inhibition [9-11]. In SpA, there is evidence for peripheral PsA responding to anti-IL12/23 or anti-p19 IL-23 blockers [12] but lack of evidence for efficacy in axial disease in AS [13] that suggests a key role for IL-17A biology in the spine that requires independent functioning of IL-17A from IL-23. The non-steroidal anti-inflammatory drugs (NSAIDs) are remarkably effective for the therapy of human AS with many patients demonstrating good and sustained responses with inflammation and sub-fibrocartilage neo-vascularisation abrogation as shown on imaging [14]. That collectively in some of these pathways (COX and IL-17 axis) inhibition is so effective in AS but not RA empirically shows that these are central to the pathology of axial SpA. Herein, we describe how excessive activity in these translationally relevant pathways may have pivotal roles in repair of SpA-related target tissue. Data from enthesis cellular immunology and translational human immunology are synthesized to explain how cytokine "fine tuning" of enthesis homeostasis and repair could be a key consideration for understanding axial SpA spectrum disease. The corollary to this is that cytokine production in "non-inflammatory" or biomechanically induced or degenerative enthesopathy may also have a role in cytokine "fine tuning" of repair to restore homeostasis. Such a scenario is not without support given that the pan-cytokine inhibition of corticosteroids may actually lead to Achilles tendon rupture [15].

\section{Linking immunity and spinal tissue repair-immunity}

The enthesis is under constant mechanical stress and in $\mathrm{SpA}$ relevant disease models this results in a pro-inflammatory cytokine production and inflammatory cell recruitment in a 
biomechanically stress dependent mechanism [16-18]. In humans, the post-inflammatory phase of axial enthesitis is associated with complete spinal fusion and a "bamboo spine" [19]. In the normal human enthesis, several immune cell types have been identified including, type 3 ILC's (innate lymphoid cells) [20], natural killer (NK) cells [21], $\gamma \delta \mathrm{T}$ cells [22] and conventional $\alpha \beta C D 4+$ and CD $8+\mathrm{T}$ cells [23]. This emergent enthesis immune system is reminiscent of that in both the skin and the gut [24], but the absence of local microbiotal communities at the enthesis raises important issues as to why such an immune system is compartmentalized at the enthesis.

GWAS studies in AS have implicated specific immune pathways associated with pathogenesis, including the IL-17/ IL-23 pathway, control of NF- $\mathrm{KB}$ activation, amino acid trimming via ERAP-1 for MHC antigen presentation and other genes controlling CD4+ and CD8+ $\mathrm{T}$ cell subsets [25]. The GWAS data incriminating lymphocytes in axial SpA is supported by rudimentarily immunology where both innate and conventional $\alpha \beta$ T cells found at the normal human enthesis have inducible key SpA associated cytokines, IL-17A and $\mathrm{TNF} \alpha[22,23,26]$. In the context of experimental SpA pathogenesis, excessive TNF or IL-17 driven immune systems activation are associated with a primary enthesitis, which may later spread to the adjacent tissues [16-18]. Of course, the TNF and IL-17 pathways have been successfully targeted in humans providing incontrovertible proof of a pivotal disease role [27, 28].

\section{Linking immunity and spinal tissue repair-tissue repair and new bone}

Important to tissue repair are resident mesenchymal stem cells (MSCs), which have been identified in almost every tissue in the human body. MSCs display a receptiveness towards an array of chemokines and cytokines which are all affiliated with tissue repair following on from injury or damage [29-31]. Notably, cytokines including IL-17A are elevated at fracture sites and capable of driving osteogenesis from local MSC populations $[32,33]$. What is also recognized in AS that NSAIDs are generally associated with the suppression of new bone formation [34] with the exception of one study which is limited by the fact that the control arm could take NSAIDs on demand [35]. In the orthopaedic setting, there is a general aversion of NSAID use for analgesia in the setting of postoperative spinal fusion surgery due to the negative impact on bone union of surgically desired segmental fusion [36, 37]. Indeed, several studies show that NSAIDs hinder mesenchymal stem cell osteogenesis [38]. Rheumatologists may not be aware but a strong interest in developing prostaglandin (PGE)2 agonists for their known bone building capabilities was mooted more than 20 years ago [39].
Whilst the role of COX inhibition on skeletal biology is fairly well defined, the role of the pivotal therapeutically antagonized cytokine molecules is less well defined. A highly pertinent observation is that the pivotal cells involved in the osteogenesis in AS, namely MSCs and other stromal cells express both TNF-R1 and IL-17RA, in addition to COX enzymes so are potentially directly impacted by licenced therapy for AS $[31,40]$. Having defined the entheseal cellular players, we look at molecules and cytokines known to be pivotal in axial enthesitis in AS in the context of tissue repair fine tuning.

\section{Prostaglandin E2}

Prostaglandin E2 (PGE2) can be produced by almost every cell in the human body, it is a lipid mediator that is synthesized from arachidonic acid via COX enzymes [41]. Prostaglandin E2 exerts its effects through four different $G$ protein-coupled receptors (EP1-EP4). EP4 is of particular interest for potential roles in AS [42] and normal bone formation [43]. Prostaglandin E2 has long been known to cause an increase in osteogenesis, with immobilized femurs of female rats treated with PGE2 showing increased osteogenesis in these immobilized bones [44]. Of considerable interest after a GWAS in AS was a single nucleotide polymorphism (SNP) at chromosome 5p13 [42]. The rs10440635 SNP in the prostaglandin E receptor 4 (PTGER4) gene is robustly associated with AS [42]. PTGER4 encodes the prostaglandin E2 receptor 4 (EP4), which when activated is seen to amplify CD40 mediated induction of IL-23 p19 expression [45]. The evidence that NSAIDS are highly effective at reducing new bone formation linked to PGE2 expression suggests at a potential role [14]. However, 2-year continuous treatment using the NSAID diclofenac did not significantly reduce radiographic progression in AS patients compared to an on-demand treatment of the same NSAID [35], which is in contrast to similar studies involving celecoxib which showed that continuous usage over a 2-year period did decrease radiographic progression of AS when compared to an on-demand treatment [46]. The Wanders et al. study is however limited in its findings; notably only $65 \%$ of patients completed the study without switching to another NSAID with their control arms also taking NSAIDs when undergoing flares which likely trigger the cycle of inflammation [46]. With NSAIDs all showing comparable levels of COX-2 inhibitions [47], the use of COX-2 selective and non-COX selective inhibitors does have an impact on bone formation. With celecoxib showing no clear difference in the prevention of hip ossification after replacement when compared to indomethacin [48], whilst another study showed superior inhibition of hip ossification for the same surgery when compared to ibuprofen [49]. 
More recently, co-culture models of classically activated M1 macrophages and MSCs demonstrated enhanced mineralisation associated with PGE2 secretion by the M1 macrophages in early phases of MSC differentiation, compared to MSCs cultured alone [39]. A significant decrease in mineralisation observed with COX-2 inhibitor was added to the culture [39]. With macrophages being elevated early at fracture sites [50], this suggests at a role for PGE2 in normal fracture repair. Murine COX-2 knockouts showed a delayed initiation and an impaired endochondral bone repair that was associated with severe angiogenesis impairment [51]. Agonists for EP4 or EP2 can rescue impaired fracture healing seen in COX-2 knockout mice [51]; they can also augment normal fracture repair in rat fracture models [52].

\section{Tumour necrosis factor}

TNF exerts its affects through two different receptors: TNFRI/ p55 and TNFRII/p75 [53]. TNFRI is expressed ubiquitously and constitutively, whilst TNFRII is only expressed on immune cells. TNF is mainly produced by myeloid cells such as macrophages, but other immune and stromal cells are capable of secretion [40]. TNF has an established role in healthy fracture repair, with TNF receptor knockouts of both TNFRI and TNFRII demonstrating delay MSC migration and a subsequent delay in endochondral tissue formation [30]. Supplementation using TNF in fracture sites results in accelerated bone repair with greater callus mineralisation 28-days post fracture [54, 55]. The migration of MSCs towards fracture sites is also seen in humans with significantly elevated levels of TNF after 72-h seen in the peri-fracture area [56], which helps drive MSC migration by upregulating expression of intercellular adhesion molecule (ICAM)-1 and vascular adhesion molecule (VCAM)-1 [57]. However, it is important that levels of TNF at the fracture site are controlled with prolonged elevated levels working synergistically with IL$1 \beta$ resulting in increased chondrocyte apoptosis and impaired chondrocyte proliferation [58]. This is associated with a decrease in subsequent new bone formation at the callus site. Interestingly, TNF stimulates tissue nonspecific alkaline phosphatase and subsequent mineralisation in the presence of collagen, independent of the RUNX2 pathway [59]. With the collagen rich environment at the enthesis, this ectopic mineralisation of the collagen fibrils could be acting as a template for calcium crystal deposition and potentially assisting in the new bone formation at the enthesis.

Elevated levels of TNF are seen to induce persistent elevation of Wnt proteins. Elevation activates NF-KB (p65) and cJun N-terminal kinase (JNK)/activator protein-1 signalling pathway leading to bone formation. However, both the canonical and non-canonical pathways are needed to induce bone formation via inflammation with inhibition of either pathway significantly decreasing bone formation [60]. Though TNF is shown to elevate levels of Dickkopf-1 (DKK-1), this is shown in mouse models to suppress Wnt signalling, allowing for enhanced bone resorption with an increase in osteoclast activator RANKL [61]. Inhibition of DKK-1 resulted in increased bone formation via Wnt signalling activation, with subsequent RANKL mediated bone resorption being blocked by osteoprotegerin (OPG) [61].

In AS, the role that DKK-1 remains contentious with various studies and meta-analyses showing contrasting results with some showing significant elevation of DKK-1 in AS $[62,63]$, others showing a significant decrease $[64,65]$ whilst some showed no significant differences [66, 67]. There is some evidence DKK-1 is dysfunctional in AS and a result is capable of abnormal activation of $\beta$-catenin independent $\mathrm{Wnt}$ signalling by binding less avidly to low-density lipoprotein receptor-related protein 6 (LRP6), a key receptor in the canonical Wnt pathway [68]. With the mixed literature on its potential affects it remains unclear what role it plays in the pathogenesis of AS. Whilst it appears that TNF can indeed fine tune or increase osteogenesis, the idea that new bone formation occurs in AS via DKK-1 in face of high TNF needs further evaluation.

\section{IL-17A and other IL-17 family cytokines in tissue repair}

IL-17A elevation was shown to contribute to fracture repair shortly after injury with $\gamma \delta \mathrm{T}$ cells being the primary source $[32,33]$. The reasoning for this increased osteogenesis is mixed within the literature with IL-17A shown to both increase osteogenesis [32] but in rat calvarial cells to decrease osteogenesis [69]. The difference in effects IL-17A has on osteogenesis is suggested to be dependent on the target cells origin. Immature mesenchymal cells such as MSCs are reported to display increase osteogenesis with exposure to IL-17A $[31,70]$, whilst calvarial pre-osteoblasts are seen to show decreased osteogenesis $[69,71]$.

Generally, it is thought that IL-17A elevation in the aftermath of a bone injury promotes bone regeneration, with murine IL-17A-/- models displaying impaired bone regeneration following drill hole in the femur at 14 and 21 days post injury compared to wild-type mice [32]. Elevation of IL-17A activates osteoblasts via JAK2/ signal transducer and activator of transcription (STAT) 3 signalling pathway, causing osteogenesis and fracture repair [31]. Inhibition of IL-17A in psoriatic arthritis (PsA) trials showed substantial reductions in small joint erosion, associated with inflammation suppression $[72,73]$. As with PsA, AS shows similar elevated levels of IL$17 \mathrm{~A}$ in both the serum and synovial fluid of patients $[31,74]$.

Emerging evidence suggests an important role for IL-17F in SpA spectrum disease and psoriasis since dual suppression 
of IL-17A and IL-17 may offer benefit, especially in the skin [75]. IL-17F expression following inflammatory stimuli can activate the CCAAT/enhancer binding protein $(\mathrm{C} / \mathrm{EBP})-\beta$ that mediates osteoblastogenesis seen in early fracture repair [76]. This is supported by a mouse tibial fracture model where IL$17 \mathrm{~F}$ is seen to be elevated 3 days after the fracture at the fracture callus demonstrating a role in fracture repair [77]. More emerging evidence is showing a synergy between IL17A and IL-17F where dual inhibition of both cytokines has a greater osteogenic suppression than inhibition of either one cytokine alone, with stimulation of periosteum-derived cells by either IL-17A or IL-17F showing equal levels of increase of osteogenesis [78].

Rag1 knocked-out mice, which prevent development of mature $\mathrm{B}$ and $\mathrm{T}$ cells, demonstrated impaired fracture healing compared to wild types and interestingly IL-17F was shown to rescue this impaired osteogenesis [77]. This increased osteogenesis by IL-17F has not only been reported on MC3T3-E1 cell lines [76], but it also increased human osteoblastic differentiation from human and mouse bone marrow derived MSCs $[70,77]$. Clearly from these experiments, it will be important to ascertain whether IL-17F dysregulation could play a role in AS related inflammation and post inflammation tissue remodelling. Of particular interest was the demonstration of two IL$17 \mathrm{~F}$ gene polymorphisms ( $7383 \mathrm{~A} / \mathrm{G}$ and $7488 \mathrm{~A} / \mathrm{G}$ ) associated with AS disease in a Turkish patient cohort [79].

The biology of other IL-17 family members is incompletely understood and given the role of IL-17A/F these are briefly summarized. Elevated levels of IL-17RB are seen in the first 2 weeks post fracture in rat long bones, with it localized to trabecular bone osteoblasts, primitive and pre-hypertrophic chondrocytes as well as localized MSCs [80]. The exact role it might play is not known or well-studied. The compelling evidence that these cytokines are involved in SpA like diseases from murine collagen-induced arthritis (CIA) models. The CIA model shows a prominent inflammatory entheseal component, which was previously regarded as an experimental bulwark of RA pathogenesis [18]. With both IL-17C and IL-17B mRNA being elevated in the arthritic paws of CIA mice, the disease is ameliorated with the addition of IL-17B antibodies [81]. Moreover, IL-17C enhanced the production of TNF from murine peritoneal exudate cells, with IL-17Ctransduced CD4+ T cells exacerbating the arthritic destruction [81]. Interestingly, the addition of IL-17E to a CIA mouse model attenuated the disease state [82]. This is associated with IL-17E role in inhibiting the differentiation of Th17 cells from CD4+ T cells, causing a subsequent reduction in proinflammatory cytokines associated with arthritis [82, 83]. Recent work on SpA synovial tissues has found that IL-17D is the most expressed IL-17 family member, with downregulation in $\mathrm{SpA}$-simulated inflammation suggesting a potential anti-inflammatory role in $\mathrm{SpA}$ though further work is needed to fully establish its role [84].

\section{Cytokines that indirectly impact on the TNF or IL-17 pathways at the enthesis}

Many cytokines regulate IL-17 axis cytokines or are the product of IL-23/17 axis stimulation and include IL-1, IL-6, TGF- $\beta$ and others and these are briefly discussed (Fig. 2). The IL-1 pathway has repeatedly been identified in GWAS in AS $[85,86]$. It is now known that IL-17 production can occur independently of IL-23 stimulation [87] and that IL-1 $\beta$ is capable of driving maturation of IL-17 producing cells [88, 89]. This supports a role for the IL-1 family in AS especially since IL-23 blockade is ineffective for spinal disease progression $[90,91]$. IL-1 $\beta$ is capable of inducing the expression of other inflammatory cytokines from CD4+ and CD8+ cells; this allows for an initiation of an inflammatory response seen in tissue repair. IL-1 $\beta$ along with IL-23 is capable of inducing the expression of IL-17 from Th17 cells, but IL- $1 \beta$ is also shown to induce the expression of IL-17, IL-21 and IL-22 from $\gamma \delta \mathrm{T}$ cells due to their expression of the transcription factor ROR $\gamma t$ (also seen on Th17 cells) [91]. IL-1 $\beta$ is also known to induce the expression of IL-6 from peripheral blood monocytes and epithelial cells $[92,93]$.

Whilst not only a driver of IL-17 production in AS, IL-1 $\beta$ and IL- $1 \alpha$ are both known to play a role in normal fracture repair with both seen to be elevated in early and late phases of fracture repair [94]. The early elevation of IL-1 acts to activate osteoclasts independent of RANKL [95]. However, if levels are abnormally elevated in rat models, this creates a fracture site haematoma with thinner fibres and a denser clot structure, inhibiting migration of stem cell populations towards the fracture site [96]. Elevated levels of IL-1 $\beta$ and the associated changes in normal healing can lead to non-union fractures or inflammatory diseases resulting in abnormal bone resorption [97]. Of note is that deficiency of the IL-1 receptor antagonist in humans, termed (DIRA), is associated with new bone formation in the spine [98], indicating that unrestrained IL-1 family activity may lead to new bone formation.

IL-6 is a pleiotropic cytokine involved in a range of biological processes both inflammatory and antiinflammatory [99]. That IL-6 is important in AS is argued against by failed trials of anti-IL-6R blockers in improving AS symptoms [100]. However, like IL-1, this cytokine is important in regulating the IL-23/17 axis where IL-6 is considered a key driver in the differentiation of de novo Th17 T cells in conjunction with IL-23 [101-103]. As mentioned above, the spinal enthesis harbours resident CD4+ and CD8+ T cell populations; both secrete IL-17A and TNF [23]. Importantly, IL-6R polymorphism has been linked to AS in large GWAS studies [104]. High levels of IL-6 are found in biopsies of sacroiliac joints of AS patients [105]. Circulating levels of IL-6 correlate with spinal inflammation [106, 107], with a significant reduction in IL-6 levels after TNF blockade [108]. In murine models, prolonged 


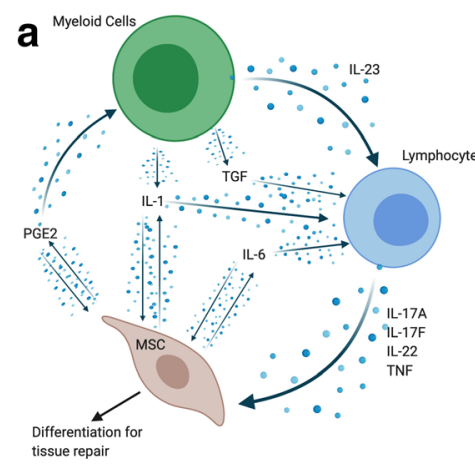

Fig. 2 a Beyond TNF and IL-17A other cytokines are indirectly involved in the axis. For example, IL-1, IL-6 and TGF-beta can prime IL-17A, IL$17 \mathrm{~F}$ and IL-22 production and genetic polymorphisms in IL-1 an IL-6 are linked to AS. Independently of the impact on IL-17 pathway biology these cytokines can also directly impact on stromal and MSC biology. b The balance between immune activation in response to mechanical

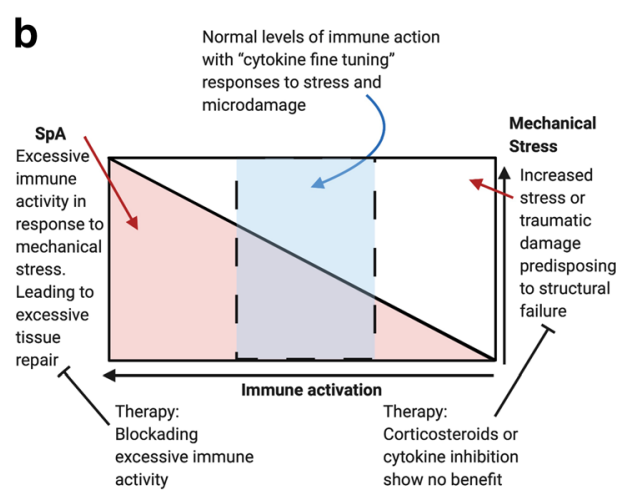

stress. Overactivation of the immune system in response to mechanical damage can lead to excessive repair as seen in SpA (red). Conversely blocking the immune system when excessive mechanical stress induced injury can be detrimental to the repair process or may render repair ineffective mastication caused accumulation of Th17 cells associated with subsequent gingival tissue repair that is driven by IL-6 upregulation in response to physiological tissue damage [109]. This ties into how both IL-17A and IL-6 affect the gastrointestinal tract beyond the oral mucosa where it where it has an important tissue protective role in intestinal barrier function [110, 111].

IL-6 is expressed by osteoblasts after a fracture has occurred due to the rapid increase in local IL- $1 \beta[94,112]$. The levels of IL- 6 decrease over the course of the fracture repair [113], which is supported by the suspected role IL-6 plays in fracture healing. Where knockouts of IL-6 in mice fractures causes a significant reduction in osteoclastogenesis and impaired callus strength, though by 6 weeks, post-fracture most of the biomechanical features of the fracture were similar to wild type mice [114]. IL-6 also has a chemotactic effect upon resident mesenchymal cells, which migrate towards the site of the fracture [94].

However, abnormal and prolonged upregulation of IL-6 can cause significant bone degradation [115]. In murine models, elevated levels of IL-6 among other cytokines discussed causes an upregulation in STAT3 activation in osteoblasts and local fibroblasts [116]. This activation of STAT3 was seen to promote expression of RANKL and subsequent osteoclastogenesis, creating a positive feedback loop resulting in the prolonged inflammation and joint destruction associated with RA [116]. Blockading of IL-6 signalling is seen to ameliorate osteoclastogenesis and joint destruction in both animal models [117, 118]. With IL-6 signalling through JAKs [119], inhibition of JAK is becoming a more viable target for SpA therapies due its indirect and direct signalling through other cytokines mentioned above [120].

Another cytokine of interest in SpA is IL-22 since it is downstream of IL-23 and induced by IL-23 signalling. Its receptor IL-22R $\alpha$ is not expressed on immune cells which creates a uni-directional signalling pathway, meaning only immune cells are seen to express IL-22, with CD4+ T cells [121], CD8 $+\mathrm{T}$ cells [122, 123], $\gamma \delta \mathrm{T}$ cells [124] and natural killer $\mathrm{T}$ cells [125] all being capable of IL22 expression. However, in ILC populations, ROR $\gamma \mathrm{t}$ activation is required to induce IL-22 expression; this is due to the induced IL-23R upregulation which is the IL-23 receptor that induces IL-22 expression form immune cells [126]. The regulation of IL-22 expression by IL-23 is seen when mTOR is blocked in neutrophils there is subsequently inhibited IL-22 expression [127]. The IL-23 signalling axis is also shown to drive activation of $\mathrm{T}$ cells, which are well known to secrete pro-inflammatory cytokines associated with AS such as IL-22 and IL-17A [18, 128]. The use of IL-23 inhibitors in AS patients for a phase two trial showed no meaningful clinical improvements [13], with rat SpA models showing the same results, unless anti IL-23 is used prophylactically when there was suppression of IL-22 [87]. This suggests at IL-22 production in a potentially independent manner from IL-23, where IL-23 is needed for disease initiation but not its continuation or progression.

IL-23, which regulates IL-22 expression, is upregulated following femoral fracture in mice and likely explains upregulation of IL-22 expression [129]. IL-22 drives the migration of MSCs towards a site of injury where elevated levels of IL22 could be present [29]. Osteogenic differentiation from MSC is enhanced by elevated IL-22; subsequently, IL-22 activates osteoblast induced bone remodelling via phosphorylation of STAT3 $[18,29]$. Interestingly, mouse primary osteoblasts display only low levels of the IL-22R $\alpha$ receptor, though its expression was upregulated when primed with bone morphogenetic protein (BMP)-2 [130]. 
Fig. 3 Overactivation of the immune system in tissue damage and excessive bone repair responses in ankylosing spondylitis. SNPs in PGE2 and IL-23/17 axis cytokines and others are clearly linked to spinal inflammation and postinflammation repair. It is proposed that the initial microdamage to the spinal enthesis as shown in Fig. 1 leads to inflammation an immune driven tissue repair response. The same cytokine TNF and IL-23/17 pathways are responsible for both inflammation and also contributing to excessive repair responses. The dysregulation of homeostatic fine tuning of tissue repair, thus results in the characteristic post inflammation disease phenotype

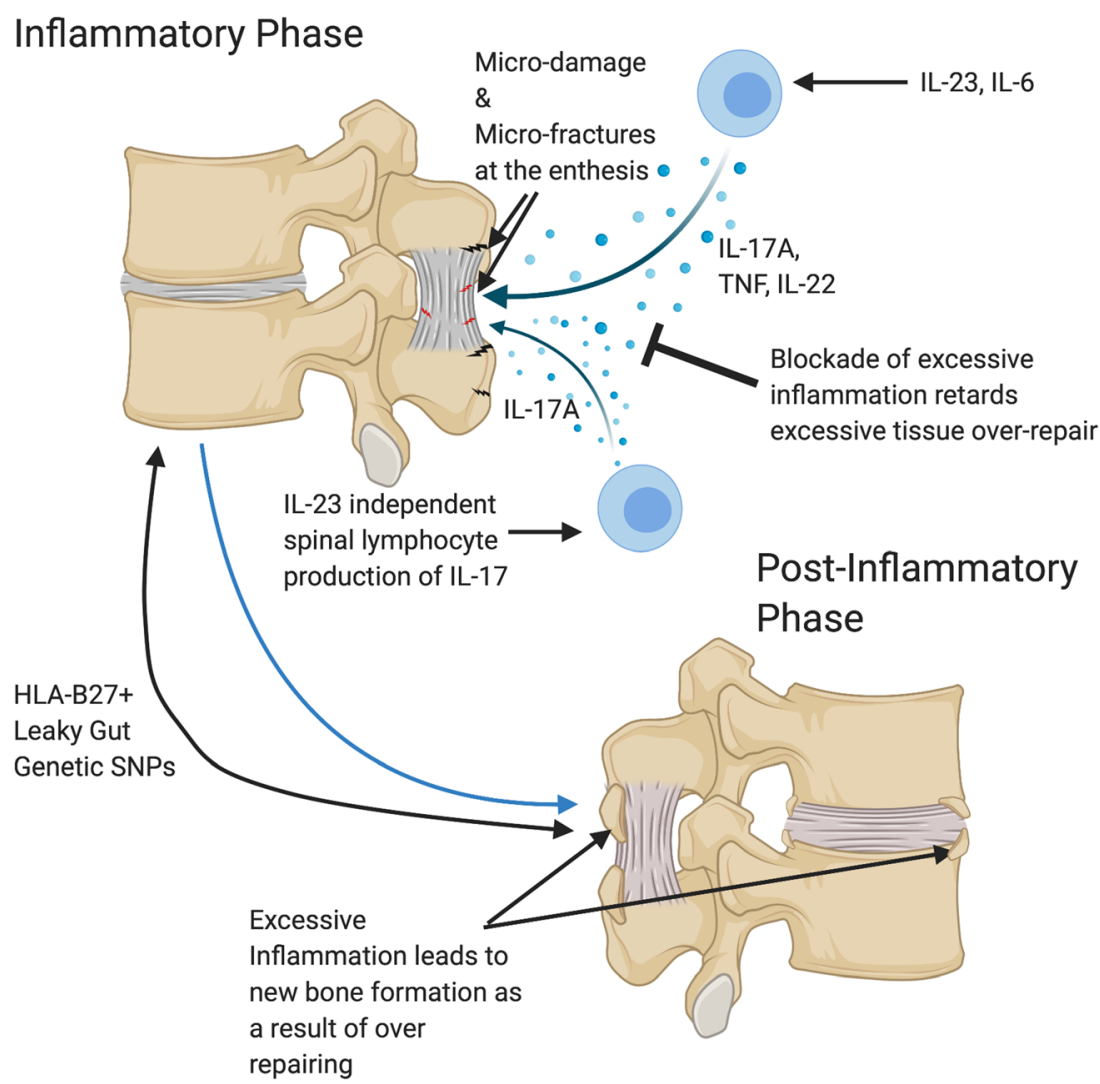

\section{Emerging cytokines in enthesis fine tuning-IL-4 and IL-13}

There has recently been a revaluation into the role of the traditional Th2 cytokines and the SpA field. IL-4 and IL-13 are classical Th2 cytokines, with a documented role in atopic dermatitis and asthma [131]. As well as driving Th2 differentiation, these cytokines are involved in $\mathrm{IgE}$ class switching. The many shared functions of IL- 4 and IL-13 is related to signalling through the common shared receptor (IL-14R $\alpha$ ). Recent data in atopic dermatitis patients undergoing dupilumab treatment (IL-4 and IL-13 blocker) reported the development of peripheral enthesitis [132]. These observations have also been supported by other case reports of enthesitis development following dupilumab therapy [133].

The mechanism surrounding IL-4/IL-13 blocking-induced enthesitis are presently unknown, but genetic associations of unknown functional significance between IL-13 and psoriatic arthritis have been reported [134-136]. It is also of note that the IL-13 genetic associations do not appear to occur in AS, given the many subtle differences between these diseases. It could be hypothesised that IL-4 and IL-13 blockage could change the differentiation of immature $\mathrm{T}$ cells from a Th2 phenotype to a Th1/Th17 phenotype with subsequent increased IL-17/IL-22 and TNF production. In support of this, we recently showed that IL-4/IL-13R cells are present in the normal enthesis, and the synovial fluid of PsA patients contains measurable IL-4 and IL-13 [137]. IL-4+ T cells are also present at the normal enthesis and IL-4/13 reduced Th17 cytokines from stimulated entheseal $\mathrm{T}$ cells [137]. It has been known for over 20 years that IL-4 has a protective role in cartilage destruction, including that induced by IL-17 [138]. In the murine CIA arthritis model, both IL-4 and IL-13 reduced symptoms and bone erosion [139, 140]; however, this model at a pathological level is far closer to RA than SpA. The role of IL-4 and IL-13 in bone modelling has also been studied with KO models. IL-4 or IL-13 KO mice both present with reduced cortical bone mass [141]. In a murine fracture model, net bone formation or mineral deposition was not effected by either IL-4 or IL-13 KO; however, subtle perturbations in associated vascularisation and innervation were noted [142].

\section{Degenerative changes at spinal and peripheral enthesis and tissue repair}

Normal spine and peripheral entheses are subject to agerelated degenerative changes around the annulus and other entheseal structures. Even in AS, there is ample evidence of substantial degenerative changes reported around the 
spinal discs [143], so theoretically, such changes may be important in what is considered as mainly inflammatory disease. There is very little specific research relating to degenerative enthesopathy in the spine but more data from the peripheral skeleton including tendinopathy including the Achilles tendon. This latter process is not focussed at the insertional site but more proximal at the synovio-entheseal complex structure [144].

The early phases of degenerative tendinopathies have a clear signature of an inflammatory phenotype [145]. Shortly after damage, rapid accumulation of neutrophils is seen in tendons, with subsequent macrophage accumulation over time [145], though more immunologically active cells are also seen to be elevated in early pathogenic tendons, namely populations of $\mathrm{T}$ cells, natural killer cells and mast cells [146, 147]. Significant elevations of IL-17 are seen in samples of early tendinopathy taken from the subscapularis, compared to both torn supraspinatus and healthy control tendons [147]. Tenocytes in culture when stimulated by IL-17 significantly increase secretions of TNF, IL-6 and IL- 8 which is supported by the gene analysis of human tendinopathy patients [147, 148]. Not only is there an increase in cytokines with IL-17 stimulation, with resultant tenocytes collagen type III deposition as opposed to the healthy collagen type I phenotype, which creates a weaker overall tissue structure due to the loss of organization [147, 149]. Accordingly, immune activation in site of excessive damage may represent an exuberant attempted repair response rather than a detrimental one that is seen in axial SpA (Fig. 3). The detrimental impact of corticosteroids on tendinopathy may in part be due to antagonism of this immune-driven repair element [15, 150] (Fig. 4). Just like corticosteroids, it may be that the TNF and IL-17 will not impact on tissue repair or provide benefit in these more degenerative settings.

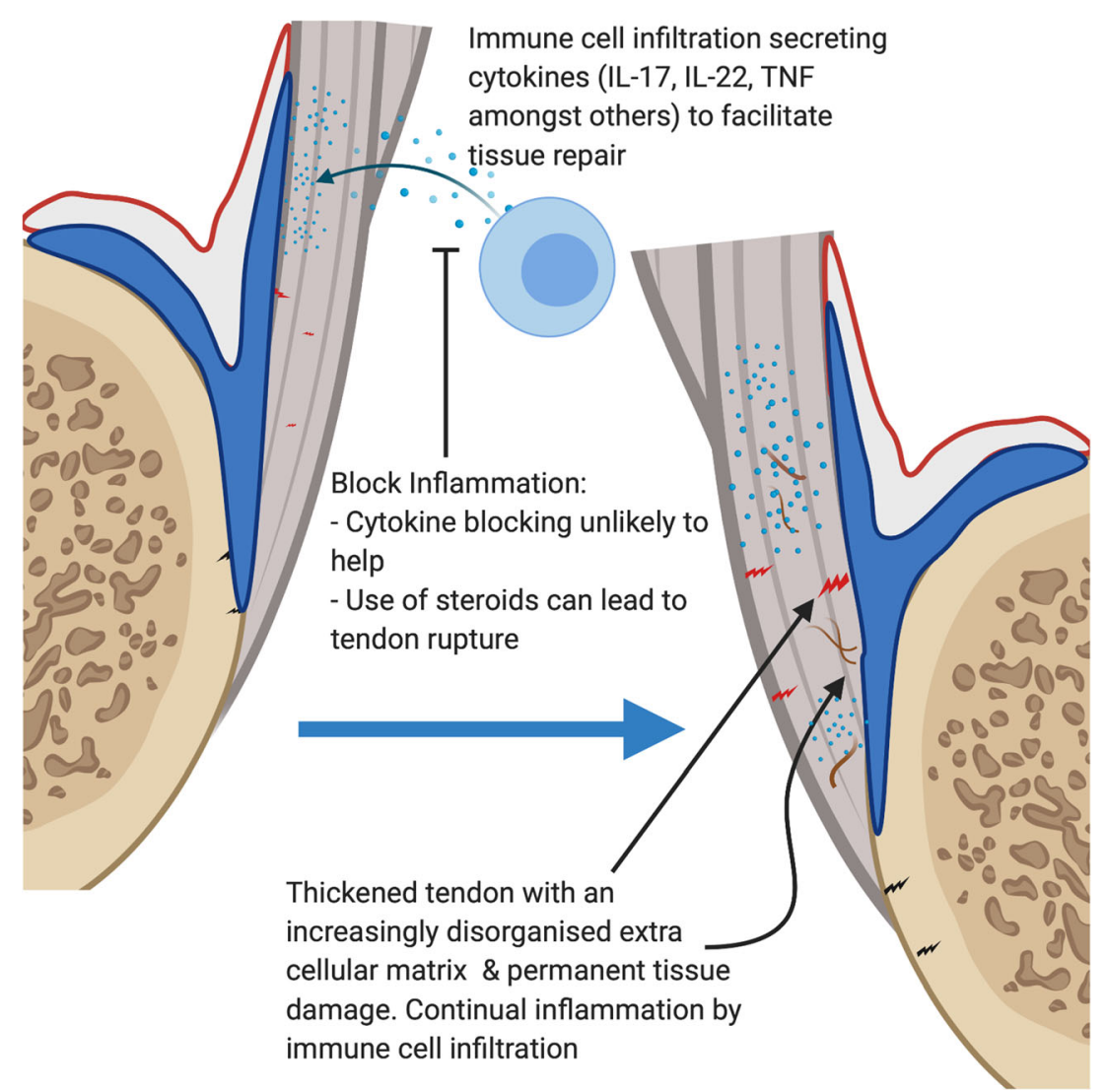

Fig. 4 Inflammation in tendinopathy. The synovio-entheseal complex with tendons wrapping around bony tuberosities shows how the enthesis is more than merely a focal attachment site leading to stress dissipation over a wide area. Micro-damage at the Achilles tendon enthesis organ in chronic tendinopathy at this and other tendon locations near attachment points leads to immune cell infiltration to aid in tissue repair. However, unlike $\mathrm{SpA}$, the excessive microdamage and injury may lead to persistent and elevated local immune responses or increased immune system fine tuning in an attempt to restore homeostasis. Prolonged inflammation may in theory contribute to tendinopathies, with thickening of the tendon and gradual loss of extra cellular matrix organization weakening the tendon. Unlike SpA where cytokine blockade efficiently controls disease by modulating the excessive immune fine tuning of cytokine homeostasis in a normal biomechanical environment, the situation here is different. The primary issue may be an abnormal biomechanical environment where the cell infiltration and associated physiological increase in fine tuning represents a repair attempt. The use of corticosteroids can lead to tendon ruptures highlighting an important role in a controlled amount of inflammation in tissue repair 
In the spine, there is no compelling evidence that TNF blockers impact beneficially on degenerative disease nor do they exacerbate [151]. This supports the cytokine fine tuning theory of entheses and sites of high stress. Dysregulation of this fine tuning in immune driven inflammation can be usefully antagonized with TNF and IL-17 pathway inhibition, but we expect that ongoing efforts to antagonize attempted cytokine fine tuning towards repair in primary degenerative or biomechanically related enthesopathies will fail.

\section{Conclusions}

It is clear that the normal enthesis has a resident immune system, and in experimental studies, there is ample evidence that this plays a role in the normal entheseal tissue repair. Excessive tissue repair is the hallmark of human spinal enthesitis-related pathology, and certain cytokines including TNF and IL-17A are clearly involved as demonstrated by human studies. Akin to the skin and the gut, dysregulation of the enthesis resident immune system can often lead to disease states affiliated with initial destruction but eventual excessive tissue repair. The exact pathogenesis of these disease states is complicated due to the built-in redundancy seen within the immune system. In more degenerative-associated enthesopathy states, the attempted cytokine and immune fine tuning may be part of a commensurate and attempted repair response, the suppression of which may have no benefit or be detrimental.

Acknowledgements All figures were created using biorender.com

Author contributions TR, HR, CB, AA, EJ and DM all contributed to the drafting and editing of the manuscript. All the authors have read and approved the final version of the manuscript.

Funding DM is funded by the Leeds NIHR Biomedical Research Centre. Novartis UK Investigator Initiated non-clinical research funding support (HR, TR, CB).

\section{Compliance with ethical standards}

Competing interests The authors declare that they have no competing interests.

Ethical approval Not applicable

Consent to participate Not applicable.

Consent for publication Not applicable.

Data sharing statement Not applicable.
Open Access This article is licensed under a Creative Commons Attribution 4.0 International License, which permits use, sharing, adaptation, distribution and reproduction in any medium or format, as long as you give appropriate credit to the original author(s) and the source, provide a link to the Creative Commons licence, and indicate if changes were made. The images or other third party material in this article are included in the article's Creative Commons licence, unless indicated otherwise in a credit line to the material. If material is not included in the article's Creative Commons licence and your intended use is not permitted by statutory regulation or exceeds the permitted use, you will need to obtain permission directly from the copyright holder. To view a copy of this licence, visit http://creativecommons.org/licenses/by/4.0/.

\section{References}

1. Watad A, Bridgewood C, Russell T, Marzo-Ortega H, Cuthbert R, McGonagle D (2018) The early phases of ankylosing spondylitis: emerging insights from clinical and basic science. Front Immunol 9(2668):2668

2. Ostrowska M, Maslinski W, Prochorec-Sobieszek M, Nieciecki M, Sudol-Szopinska I (2018) Cartilage and bone damage in rheumatoid arthritis. Reumatologia. 56(2):111-120

3. McGonagle D, Stockwin L, Isaacs J, Emery P (2001) An enthesitis based model for the pathogenesis of spondyloarthropathy. Additive effects of microbial adjuvant and biomechanical factors at disease sites. J Rheumatol 28(10):21552159

4. Martin JC, Beriou G, Heslan M, Bossard C, Jarry A, Abidi A et al (2016) IL-22BP is produced by eosinophils in human gut and blocks IL-22 protective actions during colitis. Mucosal Immunol 9(2):539-549

5. Kanno E, Kawakami K, Ritsu M, Ishii K, Tanno H, Toriyabe S, et al. Wound healing in skin promoted by inoculation with Pseudomonas aeruginosa PAO1: the critical role of tumor necrosis factor-alpha secreted from infiltrating neutrophils. Wound repair and regeneration : official publication of the Wound Healing Society [and] the European Tissue Repair Society. 2011;19(5): $608-21$

6. Javed Q, Murtaza I (2013) Therapeutic potential of tumour necrosis factor-alpha antagonists in patients with chronic heart failure. Heart, lung \& circulation 22(5):323-327

7. Shaw TJ, Martin P (2009) Wound repair at a glance. J Cell Sci 122(Pt 18):3209-3213

8. Mortier C, Govindarajan S, Venken K, Elewaut D. It Takes "Guts" to Cause Joint Inflammation: Role of Innate-Like T Cells. 2018;9(1489)

9. Baeten D, Baraliakos X, Braun J, Sieper J, Emery P, van der Heijde D, et al. Anti-interleukin-17A monoclonal antibody secukinumab in treatment of ankylosing spondylitis: a randomised, double-blind, placebo-controlled trial. Lancet (London, England). 2013;382(9906):1705-13

10. Sieper J, Deodhar A, Marzo-Ortega H, Aelion JA, Blanco R, JuiCheng T, Andersson M, Porter B, Richards HB, MEASURE 2 Study Group (2017) Secukinumab efficacy in anti-TNF-naive and anti-TNF-experienced subjects with active ankylosing spondylitis: results from the MEASURE 2 study. Ann Rheum Dis 76(3):571592

11. Balazcs E, Sieper J, Bickham K, Mehta A, Frontera N, Stryszak P, Popmihajlov Z, Peloso PM (2016) A randomized, clinical trial to assess the relative efficacy and tolerability of two doses of etoricoxib versus naproxen in patients with ankylosing spondylitis. BMC Musculoskelet Disord 17(1):426 
12. Gordon KB, Strober B, Lebwohl M, Augustin M, Blauvelt A, Poulin Y, et al. Efficacy and safety of risankizumab in moderate-to-severe plaque psoriasis (UltIMMa-1 and UltIMMa2): results from two double-blind, randomised, placebo-controlled and ustekinumab-controlled phase 3 trials. Lancet (London, England). 2018;392(10148):650-61

13. Baeten D, Ostergaard M, Wei JC, Sieper J, Jarvinen P, Tam LS et al (2018) Risankizumab, an IL-23 inhibitor, for ankylosing spondylitis: results of a randomised, double-blind, placebo-controlled, proof-of-concept, dose-finding phase 2 study. Ann Rheum Dis 77(9):1295-1302

14. Wang R, Dasgupta A, Ward MM (2016) Comparative efficacy of non-steroidal anti-inflammatory drugs in ankylosing spondylitis: a Bayesian network meta-analysis of clinical trials. Ann Rheum Dis 75(6):1152-1160

15. Kanayama G, DeLuca J, Meehan WP 3rd, Hudson JI, Isaacs S, Baggish A et al (2015) Ruptured tendons in anabolic-androgenic steroid users: a cross-sectional cohort study. Am J Sports Med 43(11):2638-2644

16. Jacques P, Lambrecht S, Verheugen E, Pauwels E, Kollias G, Armaka M, Verhoye M, van der Linden A, Achten R, Lories RJ, Elewaut D (2014) Proof of concept: enthesitis and new bone formation in spondyloarthritis are driven by mechanical strain and stromal cells. Ann Rheum Dis 73(2):437-445

17. Cambre I, Gaublomme D, Burssens A, Jacques P, Schryvers N, De Muynck A et al (2018) Mechanical strain determines the sitespecific localization of inflammation and tissue damage in arthritis. Nat Commun 9(1):4613

18. Sherlock JP, Joyce-Shaikh B, Turner SP, Chao CC, Sathe M, Grein J, Gorman DM, Bowman EP, McClanahan TK, Yearley JH, Eberl G, Buckley CD, Kastelein RA, Pierce RH, LaFace DM, Cua DJ (2012) IL-23 induces spondyloarthropathy by acting on ROR-gammat+ CD3+CD4-CD8- entheseal resident T cells. Nat Med 18(7):1069-1076

19. Zhu W, He X, Cheng K, Zhang L, Chen D, Wang X, Qiu G, Cao X, Weng X (2019) Ankylosing spondylitis: etiology, pathogenesis, and treatments. Bone Res 7:22

20. Cuthbert RJ, Fragkakis EM, Dunsmuir R, Li Z, Coles M, MarzoOrtega $\mathrm{H}$, et al. Brief report: group 3 innate lymphoid cells in human enthesis. Arthritis \& rheumatology (Hoboken, NJ). 2017;69(9):1816-22

21. Gaur P, Misra R, Aggarwal A (2015) Natural killer cell and gamma delta $\mathrm{T}$ cell alterations in enthesitis related arthritis category of juvenile idiopathic arthritis. Clin Immunol 161(2):163-169

22. Cuthbert RJ, Watad A, Fragkakis EM, Dunsmuir R, Loughenbury P, Khan A, Millner PA, Davison A, Marzo-Ortega H, Newton D, Bridgewood C, McGonagle DG (2019) Evidence that tissue resident human enthesis gammadeltaT-cells can produce IL-17A independently of IL-23R transcript expression. Ann Rheum Dis 78(11):1559-1565

23. Watad A, Rowe H, Russell T, Zhou Q, Anderson LK, Khan A, et al. Normal human enthesis harbours conventional CD4+ and CD8+ T cells with regulatory features and inducible IL-17A and TNF expression. 2020;79(8):1044-54

24. McGonagle D, Aydin SZ, Gül A, Mahr A, Direskeneli H (2015) 'MHC-I-opathy'-unified concept for spondyloarthritis and Behçet disease. Nat Rev Rheumatol 11(12):731-740

25. Tsui FW, Tsui HW, Akram A, Haroon N, Inman RD (2014) The genetic basis of ankylosing spondylitis: new insights into disease pathogenesis. Appl Clin Genet 7:105-115

26. Bridgewood C, Watad A, Russell T, Palmer TM, Marzo-Ortega H, Khan A, Millner PA, Dunsmuir R, Rao A, Loughenbury P, Wittmann M, Cuthbert RJ, McGonagle DG (2019) Identification of myeloid cells in the human enthesis as the main source of local IL-23 production. Ann Rheum Dis 78(7):929-933
27. van den Berg WB, McInnes IB (2013) Th17 cells and IL-17 afocus on immunopathogenesis and immunotherapeutics. Semin Arthritis Rheum 43(2):158-170

28. Holbrook J, Lara-Reyna S, Jarosz-Griffiths H, McDermott M. Tumour necrosis factor signalling in health and disease. F1000Res. 2019;8

29. El-Zayadi AA, Jones EA, Churchman SM, Baboolal TG, Cuthbert RJ, El-Jawhari JJ, et al. Interleukin-22 drives the proliferation, migration and osteogenic differentiation of mesenchymal stem cells: a novel cytokine that could contribute to new bone formation in spondyloarthropathies. Rheumatology (Oxford, England). 2017;56(3):488-93

30. Gerstenfeld LC, Cho TJ, Kon T, Aizawa T, Tsay A, Fitch J, Barnes GL, Graves DT, Einhorn TA (2003) Impaired fracture healing in the absence of TNF-alpha signaling: the role of TNFalpha in endochondral cartilage resorption. Journal of bone and mineral research : the official journal of the American Society for Bone and Mineral Research. 18(9):1584-1592

31. Jo S, Wang SE, Lee YL, Kang S, Lee B, Han J, Sung IH, Park YS, Bae SC, Kim TH (2018) IL-17A induces osteoblast differentiation by activating JAK2/STAT3 in ankylosing spondylitis. Arthritis research \& therapy 20(1):115

32. Ono T, Okamoto K, Nakashima T, Nitta T, Hori S, Iwakura Y, Takayanagi H (2016) IL-17-producing gammadelta T cells enhance bone regeneration. Nat Commun 7:10928

33. Ono T, Takayanagi H (2017) Osteoimmunology in bone fracture healing. Current osteoporosis reports 15(4):367-375

34. Poddubnyy D, Rudwaleit M, Haibel H, Listing J, MarkerHermann E, Zeidler H et al (2012) Effect of non-steroidal antiinflammatory drugs on radiographic spinal progression in patients with axial spondyloarthritis: results from the German Spondyloarthritis Inception Cohort. Ann Rheum Dis 71(10): 1616-1622

35. Sieper J, Listing J, Poddubnyy D, Song IH, Hermann KG, Callhoff J, Syrbe U, Braun J, Rudwaleit M (2016) Effect of continuous versus on-demand treatment of ankylosing spondylitis with diclofenac over 2 years on radiographic progression of the spine: results from a randomised multicentre trial (ENRADAS). Ann Rheum Dis 75(8):1438-1443

36. Sivaganesan A, Chotai S, White-Dzuro G, McGirt MJ, Devin CJ (2017) The effect of NSAIDs on spinal fusion: a cross-disciplinary review of biochemical, animal, and human studies. European spine journal : official publication of the European Spine Society, the European Spinal Deformity Society, and the European Section of the Cervical Spine Research Society 26(11):2719-2728

37. Dumont AS, Verma S, Dumont RJ, Hurlbert RJ (2000) Nonsteroidal anti-inflammatory drugs and bone metabolism in spinal fusion surgery: a pharmacological quandary. J Pharmacol Toxicol Methods 43(1):31-39

38. Yoon DS, Yoo JH, Kim YH, Paik S, Han CD, Lee JW (2010) The effects of COX-2 inhibitor during osteogenic differentiation of bone marrow-derived human mesenchymal stem cells. Stem Cells Dev 19(10):1523-1533

39. Lu LY, Loi F, Nathan K, Lin TH, Pajarinen J, Gibon E, Nabeshima A, Cordova L, Jämsen E, Yao Z, Goodman SB (2017) Pro-inflammatory M1 macrophages promote osteogenesis by mesenchymal stem cells via the COX-2-prostaglandin E2 pathway. J Orthop Res 35(11):2378-2385

40. Grine L, Dejager L, Libert C, Vandenbroucke RE (2015) An inflammatory triangle in psoriasis: TNF, type I IFNs and IL-17. Cytokine Growth Factor Rev 26(1):25-33

41. Smith WL (1989) The eicosanoids and their biochemical mechanisms of action. The Biochemical journal. 259(2):315-324

42. Evans DM, Spencer CC, Pointon JJ, Su Z, Harvey D, Kochan G et al (2011) Interaction between ERAP1 and HLA-B27 in 
ankylosing spondylitis implicates peptide handling in the mechanism for HLA-B27 in disease susceptibility. Nat Genet 43(8):761767

43. Graham S, Gamie Z, Polyzois I, Narvani AA, Tzafetta K, Tsiridis E, Helioti M, Mantalaris A, Tsiridis E (2009) Prostaglandin EP2 and EP4 receptor agonists in bone formation and bone healing: in vivo and in vitro evidence. Expert Opin Investig Drugs 18(6): 746-766

44. Akamine T, Jee WS, Ke HZ, Li XJ, Lin BY (1992) Prostaglandin E2 prevents bone loss and adds extra bone to immobilized distal femoral metaphysis in female rats. Bone. 13(1):11-22

45. Ma X, Aoki T, Narumiya S (2016) Prostaglandin E2-EP4 signaling persistently amplifies CD40-mediated induction of IL-23 p19 expression through canonical and non-canonical NF-kappaB pathways. Cellular \& molecular immunology 13(2):240-250

46. Wanders A, Heijde D, Landewe R, Behier JM, Calin A, Olivieri I et al (2005) Nonsteroidal antiinflammatory drugs reduce radiographic progression in patients with ankylosing spondylitis: a randomized clinical trial. Arthritis Rheum 52(6):1756-1765

47. Vane SJ (1998) Differential inhibition of cyclooxygenase isoforms: an explanation of the action of NSAIDs. J Clin Rheumatol 4(5 Suppl):s3-s10

48. Romanò CL, Duci D, Romanò D, Mazza M, Meani E (2004) Celecoxib versus indomethacin in the prevention of heterotopic ossification after total hip arthroplasty. J Arthroplast 19(1):14-18

49. Saudan M, Saudan P, Perneger T, Riand N, Keller A, Hoffmeyer P (2007) Celecoxib versus ibuprofen in the prevention of heterotopic ossification following total hip replacement: a prospective randomised trial. J Bone Joint Surg Br 89(2):155-159

50. Schlundt C, El Khassawna T, Serra A, Dienelt A, Wendler S, Schell H et al (2018) Macrophages in bone fracture healing: their essential role in endochondral ossification. Bone. 106:78-89

51. Xie C, Liang B, Xue M, Lin AS, Loiselle A, Schwarz EM et al (2009) Rescue of impaired fracture healing in COX-2-/- mice via activation of prostaglandin E2 receptor subtype 4. Am J Pathol 175(2):772-785

52. Li M, Ke HZ, Qi H, Healy DR, Li Y, Crawford DT et al (2003) A novel, non-prostanoid EP2 receptor-selective prostaglandin E2 agonist stimulates local bone formation and enhances fracture healing. Journal of bone and mineral research : the official journal of the American Society for Bone and Mineral Research. 18(11): 2033-2042

53. Daub H, Traxler L, Ismajli F, Groitl B, Itzen A, Rant U (2020) The trimer to monomer transition of tumor necrosis factor-alpha is a dynamic process that is significantly altered by therapeutic antibodies. Sci Rep 10(1):9265

54. Glass GE, Chan JK, Freidin A, Feldmann M, Horwood NJ, Nanchahal J (2011) TNF-alpha promotes fracture repair by augmenting the recruitment and differentiation of muscle-derived stromal cells. Proc Natl Acad Sci U S A 108(4):1585-1590

55. Chan JK, Glass GE, Ersek A, Freidin A, Williams GA, Gowers K, Espirito Santo AI, Jeffery R, Otto WR, Poulsom R, Feldmann M, Rankin SM, Horwood NJ, Nanchahal J (2015) Low-dose TNF augments fracture healing in normal and osteoporotic bone by up-regulating the innate immune response. EMBO molecular medicine 7(5):547-561

56. Currie HN, Loos MS, Vrana JA, Dragan K, Boyd JW (2014) Spatial cytokine distribution following traumatic injury. Cytokine. 66(2):112-118

57. Lu ZY, Chen WC, Li YH, Li L, Zhang H, Pang Y et al (2016) TNF-alpha enhances vascular cell adhesion molecule-1 expression in human bone marrow mesenchymal stem cells via the NF-kappaB, ERK and JNK signaling pathways. Mol Med Rep 14(1):643-648

58. Fernandez-Vojvodich P, Karimian E, Savendahl L (2011) The biologics anakinra and etanercept prevent cytokine-induced growth retardation in cultured fetal rat metatarsal bones. Hormone research in paediatrics 76(4):278-285

59. Ding J, Ghali O, Lencel P, Broux O, Chauveau C, Devedjian JC, Hardouin P, Magne D (2009) TNF-alpha and IL-1beta inhibit RUNX2 and collagen expression but increase alkaline phosphatase activity and mineralization in human mesenchymal stem cells. Life Sci 84(15-16):499-504

60. Li X, Wang J, Zhan Z, Li S, Zheng Z, Wang T, et al. Inflammation intensity-dependent expression of osteoinductive Wnt proteins is critical for ectopic new bone formation in ankylosing spondylitis. Arthritis \& rheumatology (Hoboken, NJ). 2018

61. Diarra D, Stolina M, Polzer K, Zwerina J, Ominsky MS, Dwyer D, Korb A, Smolen J, Hoffmann M, Scheinecker C, van der Heide D, Landewe R, Lacey D, Richards WG, Schett G (2007) Dickkopf-1 is a master regulator of joint remodeling. Nat Med 13(2):156-163

62. Sun W, Tian L, Jiang L, Zhang S, Zhou M, Zhu J et al (2018) Sclerostin rather than Dickkopf-1 is associated with mSASSS but not with disease activity score in patients with ankylosing spondylitis. Clin Rheumatol

63. Zhang L, Ouyang H, Xie Z, Liang ZH, Wu XW (2016) Serum DKK-1 level in the development of ankylosing spondylitis and rheumatic arthritis: a meta-analysis. Exp Mol Med 48:e228

64. Liao HT, Lin YF, Tsai CY, Chou TC (2018) Bone morphogenetic proteins and Dickkopf-1 in ankylosing spondylitis. Scand J Rheumatol 47(1):56-61

65. Di G, Kong L, Zhao Q, Ding T. MicroRNA-146a knockdown suppresses the progression of ankylosing spondylitis by targeting dickkopf 1. Biomedicine \& pharmacotherapy = Biomedecine \& pharmacotherapie. 2018;97:1243-9

66. Sakellariou GT, Iliopoulos A, Konsta M, Kenanidis E, Potoupnis M, Tsiridis E, Gavana E, Sayegh FE (2017) Serum levels of Dkk1, sclerostin and VEGF in patients with ankylosing spondylitis and their association with smoking, and clinical, inflammatory and radiographic parameters. Joint, bone, spine : revue du rhumatisme 84(3):309-315

67. Wu M, Chen M, Ma Y, Yang J, Han R, Yuan Y, et al. Dickkopf-1 in ankylosing spondylitis: review and meta-analysis. Clinica chimica acta; international journal of clinical chemistry. 2018;481:177-83

68. Daoussis D, Liossis SN, Solomou EE, Tsanaktsi A, Bounia K, Karampetsou M et al (2010) Evidence that Dkk-1 is dysfunctional in ankylosing spondylitis. Arthritis Rheum 62(1):150-158

69. Kim YG, Park JW, Lee JM, Suh JY, Lee JK, Chang BS, Um HS, Kim JY, Lee Y (2014) IL-17 inhibits osteoblast differentiation and bone regeneration in rat. Arch Oral Biol 59(9):897-905

70. Croes M, Oner FC, van Neerven D, Sabir E, Kruyt MC, Blokhuis TJ et al (2016) Proinflammatory T cells and IL-17 stimulate osteoblast differentiation. Bone. 84:262-270

71. Shaw AT, Maeda Y, Gravallese EM (2016) IL-17A deficiency promotes periosteal bone formation in a model of inflammatory arthritis. Arthritis research \& therapy. 18(1):104

72. Nash P, Behrens F, Orbai AM, Rathmann SS, Adams DH, Benichou O, Deodhar A (2018) Ixekizumab is efficacious when used alone or when added to conventional synthetic diseasemodifying antirheumatic drugs (cDMARDs) in patients with active psoriatic arthritis and previous inadequate response or intolerance to tumour necrosis factor inhibitors. RMD open 4(2): $\mathrm{e} 000692$

73. Nicola S, Rolla G, Monti R, Brussino L (2018) Treatment of psoriatic arthritis with secukinumab: a case series. The Journal of dermatological treatment:1-11

74. Pavlovic V, Dimic A, Milenkovic S, Krtinic D (2014) Serum levels of IL-17, IL-4, and INFgamma in Serbian patients with early rheumatoid arthritis. Journal of research in medical sciences : the official journal of Isfahan University of Medical Sciences 19(1):18-22 
75. Papp KA, Merola JF, Gottlieb AB, Griffiths CEM, Cross N, Peterson L, et al. Dual neutralization of both interleukin 17A and interleukin $17 \mathrm{~F}$ with bimekizumab in patients with psoriasis: Results from BE ABLE 1, a 12-week randomized, doubleblinded, placebo-controlled phase $2 \mathrm{~b}$ trial. Journal of the American Academy of Dermatology. 2018;79(2):277-86.e10

76. Wang Y, Kim J, Chan A, Whyne C, Nam D (2018) A two phase regulation of bone regeneration: IL-17F mediates osteoblastogenesis via C/EBP-beta in vitro. Bone. 116:47-57

77. Nam D, Mau E, Wang Y, Wright D, Silkstone D, Whetstone H, Whyne C, Alman B (2012) T-lymphocytes enable osteoblast maturation via IL-17F during the early phase of fracture repair. PLoS One 7(6):e40044

78. Shah M, Maroof A, Gikas P, Mittal G, Keen R, Baeten D, et al. Dual neutralisation of IL-17F and IL-17A with bimekizumab blocks inflammation-driven osteogenic differentiation of human periosteal cells. RMD open. 2020;6(2)

79. Erkol Inal E, Gorukmez O, Eroglu S, Ozemri SS, Solak O, Gorukmez O et al (2016) Associations between polymorphisms of IL-17F and IL-17A genes with disease activity and clinical outcome of ankylosing spondylitis. Acta reumatologica portuguesa 41(3):232-239

80. Kokubu T, Haudenschild DR, Moseley TA, Rose L, Reddi AH (2008) Immunolocalization of IL-17A, IL-17B, and their receptors in chondrocytes during fracture healing. The journal of histochemistry and cytochemistry : official journal of the Histochemistry Society 56(2):89-95

81. Yamaguchi Y, Fujio K, Shoda H, Okamoto A, Tsuno NH, Takahashi K, et al. IL-17B and IL-17C are associated with TNF-alpha production and contribute to the exacerbation of inflammatory arthritis. Journal of immunology (Baltimore, Md : 1950). 2007;179(10):7128-36

82. Liu D, Cao T, Wang N, Liu C, Ma N, Tu R, Min X (2016) IL-25 attenuates rheumatoid arthritis through suppression of Th17 immune responses in an IL-13-dependent manner. Sci Rep 6:36002

83. Gumus P, Buduneli E, Biyikoglu B, Aksu K, Sarac F, Nile C et al (2013) Gingival crevicular fluid, serum levels of receptor activator of nuclear factor-kappaB ligand, osteoprotegerin, and interleukin17 in patients with rheumatoid arthritis and osteoporosis and with periodontal disease. J Periodontol 84(11):1627-1637

84. Chen S, Manning C, van Tok M, Maeda Y, Montoro D, Kim J-M et al (2020) Interleukin-17D a cytokine derived from stromal cells, attenuates joint inflammation [abstract]. Arthritis \& Rheumatology 72(S10):1-4231

85. Timms AE, Crane AM, Sims AM, Cordell HJ, Bradbury LA, Abbott A, Coyne MRE, Beynon O, Herzberg I, Duff GW, Calin A, Cardon LR, Wordsworth BP, Brown MA (2004) The interleukin 1 gene cluster contains a major susceptibility locus for ankylosing spondylitis. Am J Hum Genet 75(4):587-595

86. Li L, Shi B, Zheng W, Xing W, Zhao Y, Li F, Xin D, Jin T, Zhu Y, Yang X (2017) Association of IL-1A and IL-1B polymorphisms with ankylosing spondylitis among the Chinese Han population: a case-control study. Oncotarget. 8(17):28278-28284

87. van Tok MN, Na S, Lao CR, Alvi M, Pots D, van de Sande MGH et al (2018) The initiation, but not the persistence, of experimental spondyloarthritis is dependent on interleukin-23 signaling. Front Immunol 9:1550

88. Revu S, Wu J, Henkel M, Rittenhouse N, Menk A, Delgoffe GM, Poholek AC, McGeachy MJ (2018) IL-23 and IL-1beta drive human Th17 cell differentiation and metabolic reprogramming in absence of CD28 costimulation. Cell Rep 22(10):2642-2653

89. Mailer RK, Joly AL, Liu S, Elias S, Tegner J, Andersson J (2015) IL-1beta promotes Th17 differentiation by inducing alternative splicing of FOXP3. Sci Rep 5:14674

90. Karakus E, Halici Z, Albayrak A, Bayir Y, Demirci E, Aydin A, Ozturk-Karagoz B, Cadirci E, Ayan AK, Sahin A, Unal D (2016)
Effects of administration of amlodipine and lacidipine on inflammation-induced bone loss in the ovariectomized rat. Inflammation. 39(1):336-346

91. Sutton CE, Lalor SJ, Sweeney CM, Brereton CF, Lavelle EC, Mills KH (2009) Interleukin-1 and IL-23 induce innate IL-17 production from gammadelta $\mathrm{T}$ cells, amplifying Th17 responses and autoimmunity. Immunity. 31(2):331-341

92. Tosato G, Jones KD (1990) Interleukin-1 induces interleukin-6 production in peripheral blood monocytes. Blood. 75(6):13051310

93. Cahill CM, Rogers JT (2008) Interleukin (IL) 1beta induction of IL-6 is mediated by a novel phosphatidylinositol 3-kinasedependent AKT/IkappaB kinase alpha pathway targeting activator protein-1. J Biol Chem 283(38):25900-25912

94. Kon T, Cho TJ, Aizawa T, Yamazaki M, Nooh N, Graves D, Gerstenfeld LC, Einhorn TA (2001) Expression of osteoprotegerin, receptor activator of NF-kappaB ligand (osteoprotegerin ligand) and related proinflammatory cytokines during fracture healing. Journal of bone and mineral research : the official journal of the American Society for Bone and Mineral Research. 16(6): 1004-1014

95. Lee YM, Fujikado N, Manaka H, Yasuda H, Iwakura Y (2010) IL1 plays an important role in the bone metabolism under physiological conditions. Int Immunol 22(10):805-816

96. Wang X, Friis TE, Masci PP, Crawford RW, Liao W, Xiao Y (2016) Alteration of blood clot structures by interleukin-1 beta in association with bone defects healing. Sci Rep 6:35645

97. Guncu GN, Akman AC, Gunday S, Yamalik N, Berker E (2012) Effect of inflammation on cytokine levels and bone remodelling markers in peri-implant sulcus fluid: a preliminary report. Cytokine. 59(2):313-316

98. Ruscitti P, Cipriani P, Carubbi F, Liakouli V, Zazzeroni F, Di Benedetto P et al (2015) The role of IL-1beta in the bone loss during rheumatic diseases. Mediat Inflamm 2015:782382

99. Scheller J, Chalaris A, Schmidt-Arras D, Rose-John S (2011) The pro- and anti-inflammatory properties of the cytokine interleukin6. Biochim Biophys Acta 1813(5):878-888

100. Sieper J, Braun J, Kay J, Badalamenti S, Radin AR, Jiao L, Fiore S, Momtahen T, Yancopoulos GD, Stahl N, Inman RD (2015) Sarilumab for the treatment of ankylosing spondylitis: results of a phase II, randomised, double-blind, placebo-controlled study (ALIGN). Ann Rheum Dis 74(6):1051-1057

101. Veldhoen M, Hocking RJ, Atkins CJ, Locksley RM, Stockinger B (2006) TGFbeta in the context of an inflammatory cytokine milieu supports de novo differentiation of IL-17-producing T cells. Immunity. 24(2):179-189

102. Acosta-Rodriguez EV, Napolitani G, Lanzavecchia A, Sallusto F (2007) Interleukins 1 beta and 6 but not transforming growth factor-beta are essential for the differentiation of interleukin 17producing human T helper cells. Nat Immunol 8(9):942-949

103. Heink S, Yogev N, Garbers C, Herwerth M, Aly L, Gasperi C, Husterer V, Croxford AL, Möller-Hackbarth K, Bartsch HS, Sotlar K, Krebs S, Regen T, Blum H, Hemmer B, Misgeld T, Wunderlich TF, Hidalgo J, Oukka M, Rose-John S, SchmidtSupprian M, Waisman A, Korn T (2017) Trans-presentation of IL-6 by dendritic cells is required for the priming of pathogenic TH17 cells. Nat Immunol 18(1):74-85

104. Cortes A, Hadler J, Pointon JP, Robinson PC, Karaderi T, Leo P et al (2013) Identification of multiple risk variants for ankylosing spondylitis through high-density genotyping of immune-related loci. Nat Genet 45(7):730-738

105. Braun J, Bollow M, Neure L, Seipelt E, Seyrekbasan F, Herbst H, Eggens U, Distler A, Sieper J (1995) Use of immunohistologic and in situ hybridization techniques in the examination of sacroiliac joint biopsy specimens from patients with ankylosing spondylitis. Arthritis Rheum 38(4):499-505 
106. Bal A, Unlu E, Bahar G, Aydog E, Eksioglu E, Yorgancioglu R (2007) Comparison of serum IL-1 beta, sIL-2R, IL-6, and TNFalpha levels with disease activity parameters in ankylosing spondylitis. Clin Rheumatol 26(2):211-215

107. Visvanathan S, Wagner C, Marini JC, Baker D, Gathany T, Han J, van der Heijde D, Braun J (2008) Inflammatory biomarkers, disease activity and spinal disease measures in patients with ankylosing spondylitis after treatment with infliximab. Ann Rheum Dis 67(4):511-517

108. Pedersen SJ, Sørensen IJ, Lambert RG, Hermann KG, Garnero P, Johansen JS et al (2011) Radiographic progression is associated with resolution of systemic inflammation in patients with axial spondylarthritis treated with tumor necrosis factor $\alpha$ inhibitors: a study of radiographic progression, inflammation on magnetic resonance imaging, and circulating biomarkers of inflammation, angiogenesis, and cartilage and bone turnover. Arthritis Rheum 63(12):3789-3800

109. Dutzan N, Abusleme L, Bridgeman H, Greenwell-Wild T, Zangerle-Murray T, Fife ME, Bouladoux N, Linley H, Brenchley L, Wemyss K, Calderon G, Hong BY, Break TJ, Bowdish DME, Lionakis MS, Jones SA, Trinchieri G, Diaz PI, Belkaid Y, Konkel JE, Moutsopoulos NM (2017) On-going mechanical damage from mastication drives homeostatic Th17 cell responses at the oral barrier. Immunity. 46(1):133-147

110. Lee JS, Tato CM, Joyce-Shaikh B, Gulen MF, Cayatte C, Chen Y, Blumenschein WM, Judo M, Ayanoglu G, McClanahan TK, Li X, Cua DJ (2015) Interleukin-23-independent IL-17 production regulates intestinal epithelial permeability. Immunity. 43(4):727-738

111. Jeffery V, Goldson AJ, Dainty JR, Chieppa M, Sobolewski A. IL6 signaling regulates small intestinal crypt homeostasis. Journal of immunology (Baltimore, Md : 1950). 2017;199(1):304-11

112. Confalone E, D'Alessio G, Furia A (2010) IL-6 induction by TNFalpha and IL-1beta in an osteoblast-like cell line. International journal of biomedical science : IJBS 6(2):135-140

113. Giganti MG, Liuni F, Celi M, Gasbarra E, Zenobi R, Tresoldi I et al (2012) Changes in serum levels of TNF-alpha, IL-6, OPG, RANKL and their correlation with radiographic and clinical assessment in fragility fractures and high energy fractures. J Biol Regul Homeost Agents 26(4):671-680

114. Wallace A, Cooney TE, Englund R, Lubahn JD (2011) Effects of interleukin-6 ablation on fracture healing in mice. J Orthop Res 29(9): 1437-1442

115. Yoshida Y, Tanaka T (2014) Interleukin 6 and rheumatoid arthritis. Biomed Res Int 2014:698313

116. Mori T, Miyamoto T, Yoshida H, Asakawa M, Kawasumi M, Kobayashi T, Morioka H, Chiba K, Toyama Y, Yoshimura A (2011) IL-1beta and TNFalpha-initiated IL-6-STAT3 pathway is critical in mediating inflammatory cytokines and RANKL expression in inflammatory arthritis. Int Immunol 23(11):701-712

117. Ohtsuji M, Lin Q, Nishikawa K, Ohtsuji N, Okazaki H, Tsurui H, Amano H, Shirai T, Nishimoto N, Nishimura H, Hirose S (2015) IL-6 signal blockade ameliorates the enhanced osteoclastogenesis and the associated joint destruction in a novel FcgammaRIIBdeficient rheumatoid arthritis mouse model. Mod Rheumatol 25(2):270-277

118. Liang B, Song Z, Wu B, Gardner D, Shealy D, Song XY, et al. Evaluation of anti-IL-6 monoclonal antibody therapy using murine type II collagen-induced arthritis. J Inflamm (Lond). 2009;6: 10

119. Heinrich PC, Behrmann I, Muller-Newen G, Schaper F, Graeve L (1998) Interleukin-6-type cytokine signalling through the gp130/ Jak/STAT pathway. The Biochemical journal 334(Pt 2):297-314

120. Veale DJ, McGonagle D, McInnes IB, Krueger JG, Ritchlin CT, Elewaut D, et al. The rationale for Janus kinase inhibitors for the treatment of spondyloarthritis. Rheumatology (Oxford, England). 2018
121. Duhen T, Geiger R, Jarrossay D, Lanzavecchia A, Sallusto F (2009) Production of interleukin 22 but not interleukin 17 by a subset of human skin-homing memory T cells. Nat Immunol 10(8):857-863

122. Liu Y, Yang B, Ma J, Wang H, Huang F, Zhang J, Chen H, Wu C (2011) Interleukin-21 induces the differentiation of human Tc22 cells via phosphorylation of signal transducers and activators of transcription. Immunology. 132(4):540-548

123. Ortega C, Fernandez AS, Carrillo JM, Romero P, Molina IJ, Moreno JC et al (2009) IL-17-producing CD8+ T lymphocytes from psoriasis skin plaques are cytotoxic effector cells that secrete Th17-related cytokines. J Leukoc Biol 86(2):435-443

124. Martin B, Hirota K, Cua DJ, Stockinger B, Veldhoen M (2009) Interleukin-17-producing gammadelta $\mathrm{T}$ cells selectively expand in response to pathogen products and environmental signals. Immunity. 31(2):321-330

125. Doisne JM, Soulard V, Becourt C, Amniai L, Henrot P, HavenarDaughton C, et al. Cutting edge: crucial role of IL-1 and IL-23 in the innate IL-17 response of peripheral lymph node NK1.1- invariant NKT cells to bacteria. Journal of immunology (Baltimore, Md : 1950). 2011;186(2):662-6

126. Spits H, Cupedo T (2012) Innate lymphoid cells: emerging insights in development, lineage relationships, and function. Annu Rev Immunol 30:647-675

127. Chen F, Cao A, Yao S, Evans-Marin HL, Liu H, Wu W, et al. mTOR mediates IL-23 induction of neutrophil IL-17 and IL-22 production. Journal of immunology (Baltimore, Md : 1950). 2016;196(10):4390-9

128. Hue S, Ahern P, Buonocore S, Kullberg MC, Cua DJ, McKenzie BS et al (2006) Interleukin-23 drives innate and T cell-mediated intestinal inflammation. J Exp Med 203(11):2473-2483

129. Al-Sebaei MO, Daukss DM, Belkina AC, Kakar S, Wigner NA, Cusher D et al (2014) Role of Fas and Treg cells in fracture healing as characterized in the fas-deficient (lpr) mouse model of lupus. Journal of bone and mineral research : the official journal of the American Society for Bone and Mineral Research 29(6):14781491

130. Zhang JR, Pang DD, Tong Q, Liu X, Su DF, Dai SM (2017) Different modulatory effects of IL-17, IL-22, and IL-23 on osteoblast differentiation. Mediat Inflamm 2017:5950395

131. Gandhi NA, Pirozzi G (2017) Graham NMJEroci. Commonality of the IL-4/IL-13 pathway in atopic diseases. Expert Rev Clin Immunol 13(5):425-437

132. Willsmore ZN, Woolf RT, Hughes C, Menon B, Kirkham B, Smith C et al (2019) Development of inflammatory arthritis and enthesitis in patients on dupilumab: a case series. Br J Dermatol 181(5):1068-1070

133. Ludwig CM, Haleen H, Hsiao JL, Lio PA, Shi VY. Emerging rheumatologic reactions with Th2 blockade. Dermatologic Therapy. 2020:e14069

134. Bowes J, Eyre S, Flynn E, Ho P, Salah S, Warren RB, MarzoOrtega H, Coates L, McManus R, Ryan AW, Kane D, Korendowych E, McHugh N, FitzGerald O, Packham J, Morgan AW, Griffiths CEM, Bruce IN, Worthington J, Barton A (2011) Evidence to support IL-13 as a risk locus for psoriatic arthritis but not psoriasis vulgaris. Ann Rheum Dis 70(6):1016-1019

135. Eder L, Chandran V, Pellett F, Pollock R, Shanmugarajah S, Rosen CF, Rahman P, Gladman DD (2011) IL13 gene polymorphism is a marker for psoriatic arthritis among psoriasis patients. Ann Rheum Dis 70(9):1594-1598

136. Duffin KC, Freeny IC, Schrodi SJ, Wong B, Feng B-J, SoltaniArabshahi R, Rakkhit T, Goldgar DE, Krueger GG (2009) Association between IL13 polymorphisms and psoriatic arthritis is modified by smoking. J Investig Dermatol 129(12):2777-2783

137. Bridgewood C, Sharif K, Freeston J, Saleem B, Russell T, Watad A et al (2020) Regulation of entheseal IL-23 expression by IL-4 
and IL-13 as an explanation for arthropathy development under dupilumab therapy. Rheumatology.

138. Lubberts E, Joosten LA, van de Loo FA, van den Gersselaar LA, van den Berg WB (2000) Reduction of interleukin-17-induced inhibition of chondrocyte proteoglycan synthesis in intact murine articular cartilage by interleukin-4. Arthritis Rheum 43(6):13001306

139. Bessis N, Boissier MC, Ferrara P, Blankenstein T, Fradelizi D, Fournier C (1996) Attenuation of collagen-induced arthritis in mice by treatment with vector cells engineered to secrete interleukin-13. Eur J Immunol 26(10):2399-2403

140. Lubberts E, Joosten LA, Chabaud M, van den Bersselaar L, Oppers B, Coenen-de Roo CJ et al (2000) IL-4 gene therapy for collagen arthritis suppresses synovial IL-17 and osteoprotegerin ligand and prevents bone erosion. J Clin Invest 105(12):16971710

141. Silfverswärd CJ, Larsson S, Ohlsson C, Frost A, Nilsson O (2007) Reduced cortical bone mass in mice with inactivation of interleukin-4 and interleukin-13. J Orthop Res 25(6):725-731

142. Silfverswärd CJ, Sisask G, Larsson S, Ohlsson C, Frost A, Ljunggren Ö et al (2008) Bone formation in interleukin-4 and interleukin-13 depleted mice. Acta Orthop 79(3):410-420

143. Baraliakos X, Landewé R, Hermann KG, Listing J, Golder W, Brandt J, Rudwaleit M, Bollow M, Sieper J, van der Heijde D, Braun J (2005) Inflammation in ankylosing spondylitis: a systematic description of the extent and frequency of acute spinal changes using magnetic resonance imaging. Ann Rheum Dis 64(5):730 734

144. Benjamin M, McGonagle D (2009) The enthesis organ concept and its relevance to the spondyloarthropathies. Adv Exp Med Biol 649:57-70
145. Marsolais D, Côté CH, Frenette J (2001) Neutrophils and macrophages accumulate sequentially following Achilles tendon injury. J Orthop Res 19(6):1203-1209

146. Kragsnaes MS, Fredberg U, Stribolt K, Kjaer SG, Bendix K, Ellingsen T (2014) Stereological quantification of immunecompetent cells in baseline biopsy specimens from achilles tendons: results from patients with chronic tendinopathy followed for more than 4 years. Am J Sports Med 42(10):2435-2445

147. Millar NL, Akbar M, Campbell AL, Reilly JH, Kerr SC, McLean M, Frleta-Gilchrist M, Fazzi UG, Leach WJ, Rooney BP, Crowe LAN, Murrell GAC, McInnes IB (2016) IL-17A mediates inflammatory and tissue remodelling events in early human tendinopathy. Sci Rep 6:27149

148. Jelinsky SA, Rodeo SA, Li J, Gulotta LV, Archambault JM, Seeherman HJ (2011) Regulation of gene expression in human tendinopathy. BMC Musculoskelet Disord 12:86

149. Millar NL, Murrell GA, McInnes IB (2017) Inflammatory mechanisms in tendinopathy - towards translation. Nat Rev Rheumatol 13(2):110-122

150. Kleinman M, Gross AE (1983) Achilles tendon rupture following steroid injection. Report of three cases. J Bone Joint Surg Am 65(9): 1345-1347

151. Baraliakos X, Haibel H, Listing J, Sieper J, Braun J (2014) Continuous long-term anti-TNF therapy does not lead to an increase in the rate of new bone formation over 8 years in patients with ankylosing spondylitis. Ann Rheum Dis 73(4): $710-715$

Publisher's note Springer Nature remains neutral with regard to jurisdictional claims in published maps and institutional affiliations. 